\title{
Polémicas de Antonio de Valbuena con sus contemporáneos sobre la corrección gramatical y los defectos del Diccionario de la Academia
}

\author{
Joaquín SERRANO SERRANO \\ Universidad de León.
}

\section{Introducción}

Antonio de Valbuena -Pedrosa del Rey (León), 1844-1929-, tuvo una "popularidad estrepitosa", según Azorín"; en 1891 se contaba "entre los más leídos [...], favorito de la juventud (los muchachos entre quince y veinte se lo saben de memoria)", según Emilia Pardo Bazán'; "cuyos artículos se pagan a precio de oro", en testimonio de 1909 de J.J. Soiza Reilly ${ }^{3}$. En realidad, Valbuena fue un escritor ocupado y preocupado con el lenguaje: "Cualquier ataque a la sintaxis o a la preceptiva, por minúsculo que fuese -dice $\mathrm{A}$. Corral-, le consideraba don Antonio de Valbuena como una ofensa personal"4.

Valbuena cuidó mucho su estilo. Se lo han reconocido todos ${ }^{5}$. Pero además se ocupó y preocupó del estilo de los demás, del uso que hacían del lenguaje sus contemporáneos ${ }^{6}$. Y se preocupó de tal manera que pasó buena parte de su vida activa como periodista y escritor censurando los vicios, no solo pero principalmente lingüísticos, de otros escritores. Censuras que no se quedaban en lo general e impreciso, sino que eran muy concretas, con datos, con citas, con textos que 'de-

${ }^{1}$ En un artículo de periódico, acaso el Diario de León, probablemente de 1944, bajo el título de "Escritores leoneses. Antonio de Valbuena".

${ }^{2}$ En Nuevo Teatro Crítico, $\mathrm{n}^{\circ}$ 9, setiembre, 1891, p.83.

${ }^{3}$ Juan José Soiza Reilly, periodista argentino, publicó en 1909 Cien hombres célebres. Confesiones literarias (Barcelona, Maucci), donde incluye, pp.285-288, la entrevista a Valbuena, bajo el título de "Antonio de Valbuena, un crítico terrible".

${ }^{4}$ A. CORRAL CASTANEDO en El Norte de Castilla de 24 de febrero de 1957.

${ }^{5}$ Según Clarín, Valbuena "sabe escribir con gracia, con soltura", "es un escritor correcto, fácil, gracioso y franco" (Palique en La Ilustración Ibérica, 14 de febrero de 1885); "Valbuena fue un prosista de los buenos", dice Azorín (ib.). "Hizo auténtica literatura creativa [...] Su mérito no consiste en descubrir el 'ripio', sino en construir un texto literario (artículo periodístico) sobre el 'ripio' descubierto", dice F. MARTÍNEZ GARCÍA (Historia de la literatura leonesa, p.418). Incluso sus detractores tuvieron que reconocerle el mérito de su estilo. Pardo Bazán habla del "encantador desafeite del estilo, el sabor neto y puro del lenguaje" (ibídem); y el P.Blanco García habla de su "vis cómica" y de su "castizo y donairoso decir" (La literatura española del siglo XIX, parte II, p.260).

6 "Capaz de asesinar a un escritor para corregirle un adjetivo", ironiza Soiza Reilly, ob. cit., pp.285-86. 
mostraran' lo que él pretendía: hacer ver que esos escritos estaban llenos de "ripios"?

Los 'ripios' son el gran hallazgo de Valbuena. Publicó Ripios Aristocráticos (1883), que llegó a tener siete ediciones; Ripios Académicos (1888), que llegó a la $4^{\mathrm{a}}$ edición; Ripios Vulgares (1891), con cuatro ediciones; cuatro tomos de Ripios Ultramarinos, en 1893, 1894, 1896 y 1902, también con una $2^{\mathrm{a}}$ edición; Ripios Geográficos (1905). Más otras obras, que sin titularse 'ripios', también cultivaban el mismo género de crítica, como los cuatro tomos de $\mathrm{Fe}$ de erratas del diccionario de la Academia (1885-88), Des-Trozos literarios (1899), dos tomos de Agridulces políticos y literarios (1892 y 1893), Corrección fraterna (1910). A lo que habría que añadir el inicial Cuentos de barbería aplicados a la política (1879-80), donde ya se vislumbraba la fórmula del 'ripio'. Y eso que no llegó a publicar unos Ripios Mezclados y otros Ripios Eclesiásticos, que se anunciaron durante varios años pero que no vieron la luz. En total, quince libros publicados fustigando los errores -o que a él se lo parecían- en los escritos de sus contemporáneos o en el diccionario de la Real Academia Española de la Lengua.

Todo este caudal de 'críticas' tuvo su éxito, le dio a su autor una 'popularidad estrepitosa', pero tuvo también sus contestaciones. Y ahí enmarcamos las polémicas de Valbuena, de las que vamos a dar cuenta en este artículo.

\section{Polémica 1ª: con el periódico La Época, 1883}

En 1883 empieza a publicar una serie de artículos, en el periódico El Progreso ${ }^{8}$, bajo el título de "Ripios Aristocráticos". En estos artículos comenta, critica, y vapulea a escritores, con título aristocrático, que han escrito 'malos versos', según Valbuena. El artículo VI va dedicado al marqués de Valmar, Don Leopoldo Augusto de Cueto. Entre otras cosas, Valbuena dice de él: Valmar era un charco que hay allá en Deva, a la orilla del cual tiene don Leopoldo una casa; y como quiera que don Leopoldo [...] no solo se creía obligado a ser poeta, sino aun a ser marqués, puso los medios y logró ser llamado marqués de Valmar en el año primero de la era de Cánovas.

Le reprocha epítetos mal utilizados, expresiones disonantes o impropias y otros aspectos a través de los cuales el poeta sale ridiculi-

\footnotetext{
7 "Palabra o frase superflua que se emplea para rellenar un verso o conseguir una rima" (Diccionario del español actual, Seco et al.).

${ }^{8}$ Periódico de Madrid, democrático y cercano a los ideales republicanos.
} 
zado. La polémica empezó porque al Marqués de Valmar le salió un defensor en el periódico La Época. Lo cuenta el mismo Valbuena en el capítulo XVII de sus Ripios Aristocráticos. Un joven redactor de dicho periódico, llamado Luis Alfonso, escribe el artículo "Cascote democrático" en el que se leen frases como estas:

Soy bien criado y agradecido, y el Marqués me ha recibido siempre con suma afabilidad en su casa... Por todo ello créome con algún derecho y no escaso deber de responder...

Yo tengo al señor marqués de Valmar por uno de los más... elegantes escritores de nuestros días [...] Es senador, es gentilhombre...

$Y$ nada, en verdad, me obliga a salir a su defensa, si es que la necesita...

Yo no estamparé que el recogedor de Ripios aristocráticos sea simple, disparatado, tonto...; antes confieso sin rebozo que se barrunta talento y donaire en sus diatribas...

A este defensor del Marqués de Valmar le contesta Valbuena en el artículo XVII de sus primeros Ripios, con párrafos como éstos:

La gratitud siempre es una buena cualidad moral, que me apresuro a reconocer en don Luis, por si acaso no tuviera ocasión de reconocerle otras literarias; siempre es una buena virtud y hasta una razón de bastante poder para explicar la defensa de don Luis, aunque no de bastante fuerza para hacer que los versos malos del marqués de Valmar dejen de ser malos [...]

Porque tampoco es defensa decir que don Leopoldo es académico. ¡Claro que no! ¡Pues vaya una defensa! iSi hoy día llamarle a uno académico y llamarle majadero y mal escritor o decirle que es un as y otras dos letras viene a ser todo uno!...

\section{Polémica $2^{\mathrm{a}}$ : con Manuel Cañete, 1883}

En el mismo 1883 y con motivo de los mismos artículos de "Ripios Aristocráticos" mantiene Valbuena una segunda polémica mucho más dura, ahora con Manuel Cañete ${ }^{9}$. La información nos la da el crítico en el capítulo XV de sus Ripios.

${ }^{9}$ Manuel Cañete nació en Sevilla, 1822. Según A. ZAMORA VICENTE ( $\mathrm{La}$ Real Academia Española, p.205) trabajó en menesteres teatrales e inició en 1840 sus primeros pasos literarios. Se fue dando a conocer por medio de los periódicos y representó algunas comedias. Publicó obras de poesía. Entró en la RAE el 8 de diciembre de 1858 y se caracterizó por su laboriosidad. También perteneció a la Academia de Historia y a la de Bellas Artes. "De un modo u otro -leemos en A. Zamora Vicente, p.240, nota 138-, la voz de Cañete se hizo oír en todo el mundillo literario del siglo XIX”. Cañete murió en noviembre de 1891. 
Manuel Cañete publicaba una sección de "Cartas Literarias" en El Diario de la Marina de La Habana. Y en una de esas 'cartas' escribió:

Mientras los hombres de fundamento se consagran en nuestros Liceos y Academias a graves estudios, ansiosos de propagar el verdadero saber, o dedican sus ocios a producir obras de ingenio, no engendradas en lo erial de lo pedestre, ni crecidas en el lodazal de la chabacanería y de lo inmundo, algunos individuos pertenecientes a la tropa ligera del periodismo, en parte de la cual suele competir la ignorancia con la insolencia..., se divierten en maltratarlos y denigrarlos en escritos groseros e insulsos [...]

Sugiérenme estas reflexiones ciertos artículos publicados en $\mathrm{El}$ Progreso, diario democrático de esta corte, firmados con el pseudónimo de Venancio González ${ }^{10}$ y destinados a fustigar impíamente los que el autor o autores de esos engendros califican de ripios aristocráticos. Las sandeces en que abundan dichos artículos, cuyos padres por lo visto están tan ayunos de ingenio como de ciencia, se dirigen con saña implacable a babosear las poesías o las obras en prosa de personas tan beneméritas como los marqueses de Molins y Valmar, a quienes tanto debe la literatura desde hace más de cuarenta años.

A Valbuena le produjo gran malestar esta carta de Manuel Cañete y en adelante se ensañará con él en multitud de ocasiones. Le dedica los capítulos XV y XXVI de sus Ripios Aristocráticos, y vuelve sobre él en dos capítulos de sus Ripios Académicos, el capítulo V y el VI. Más las citas aisladas que de él hace en otros libros y ocasiones. Resumimos las diatribas de Valbuena. En el cap.XV de Ripios Aristocráticos leemos afirmaciones de este tipo:

Pues don Manuel Cañete o Cucañete, que de ambas maneras le llamo yo, es un académico, por decirlo así, de la Lengua.......]

Señor don Manuel... estaba por llamarle a usted mamarracho.

Pero no; no se lo llamo a usted por dos razones: la primera, por no echar a perder el mote; y la segunda, porque no quiero imitarle a usted en lo descompuesto del lenguaje. [...]

... pero como no hay nadie en el mundo que no sirva para alguna cosa y que no tenga su especialidad, usted, que no sirve para escritor, es usted un excelente acumulador de salarios. Y uno por la Academia, otro por Fomento o por Gracia y Justicia, otro por una empresa particular de beneficencia, otro por el periódico de Cuba, en fin, que

${ }^{10}$ Valbuena firmó buena parte de su producción con los pseudónimos de Venancio González y Miguel de Escalada. 
reúne usted lo necesario para comer en Los Cisnes todos los días que no está usted convidado en casa de alguno de esos marqueses productores de ripios. Clarín dice que le ha visto a usted muchas veces.[...]

¡Vaya con el Sr. Ca... ca... ñete o Cucañete, qué vocabulario ha sacado a última hora! [...]

Le refriego a usted así sus productos por los hocicos [...]

Y todavía acaba Valbuena el artículo con una cita del El Español, donde se acusa a Cañete de "que se pasa la vida dando los grandes bombos a los poetas americanos. Todo porque ellos le mandan tabaco de la Habana". Por lo que concluye dicho periódico que "El señor Cañete no es, pues, autoridad. ¡Es un crítico subvencionado con nicotina!".

Pero a Cañete tenía reservados Valbuena otros ataques: son dos artículos en los Ripios Académicos de 1888: los capítulos V y VI. En el capítulo V empieza así:

Ustedes habrán oído decir que D. Manuel Cañete es poeta, y crítico, y hablista...

Pues han de saber ustedes que no hay tales Cañetes.

Vamos, que D. Manuel no es hablista, ni crítico, ni poeta, ni nada.

Por eso es académico.

Pasa después Valbuena a mostrar que Cañete no es 'hablista', no es 'crítico'; y cuando llega a "Como poeta", toma su libro Poesías, publicado en $1859^{11}$, y comienza a hacerle reparos: que pone títulos muy largos, que tiene trasposiciones ridículas ("la del hombre encuentra"), expresiones inadecuadas ("sus quebrados ojos", "rendiste el cuello" aplicado al fuego, "roca fulminada", "agostado seno"); homonimias forzadas ("hierro... yerro"). En el capítulo VI de los mismos Ripios Académicos continúa Valbuena diseccionando versos de Cañete. Ahora le reconoce "una buena cualidad: la de no ser fecundo. Afortunadamente ha compuesto usted, o mejor dicho, ha descompuesto usted muy poco". Le achaca componer poemas de circunstancias. Por ejemplo, dedica Cañete un soneto a la reina Isabel II con motivo de un atentado, y Valbuena le afea los adjetivos: Naturalmente. El brazo de Dios es soberano. Como también es el poderío noble, y

${ }^{11}$ De este libro de Poesías dice A. Zamora Vicente (ob. cit. p.205): "Era una producción no romántica, aun cercana a lo sevillano que conoció de joven y que procuró acercar a la vena política". 
el crimen adusto, y la traición cobarde, y el pecho frío, y el rayo impío, y seco el estío, y así sucesivamente: todo con trufas, como dice el personaje de los pavos reales.

A la llegada de Alfonso XII compone Cañete otros versos, que le comenta el crítico:

" $i$ Viniste al fin...!

¡Hombre, no! Vino al principio, me parece. Al fin, lo que hizo fue marcharse; es decir, morirse, que para el caso lo mismo da:

Viniste al fin! Como tras noche oscura de tormenta y de horror... (Pase el trasnoche.)

$Y$ no contento con ese tras... noche empieza el segundo cuarteto con otro:

"Tras noche horrible de infernal locura brillas, astro de amor...

Brillas as...tro. ¡Qué desastrosa combinación de palabras!

Y continúa Valbuena censurando palabras, combinaciones, disonancias, inadecuaciones... en los versos de Cañete, para terminar el artículo:

¡D. Manuel, D. Manuel...! ¿Y a estas cosas llama usted poesías? ¡Qué han de ser poesías, hombre! Estas son cañeterías y... nada más.

En esta polémica de Valbuena con Cañete también participó -de alguna manera- Leopoldo Alas "Clarín". Al publicarse la $2^{\mathrm{a}}$ edición de los Ripios Aristocráticos, Antonio de Valbuena, que siempre se llevó muy bien con Clarín, le regala un ejemplar, y Clarín aprovecha la ocasión para redactar un Palique, que publica en La Ilustración Ibérica el 14 de febrero de $1885^{12}$, y donde leemos cosas tan favorables a Valbuena como éstas:

Los poetas aristócratas de Venancio González ${ }^{13}$ no tienen genio, ni saben gramática. $Y$ Venancio González sabe mucha gramática y tiene mucho ingenio; y el ingenio es más castizo que el genio y más seguro. Es moneda que se falsifica menos.[...]

${ }^{12}$ Este "Palique" lo reproduce en adelante Valbuena en el "Prólogo" a las siguientes ediciones de Ripios Aristocráticos. También alude a él y reproduce unas líneas J.M MARTÍNEZ CACHERO en su "Introducción" a la edición de Palique de Clarín, en Labor, p.35.

${ }^{13}$ Uno de los seudónimos de Valbuena, como ya antes vimos. 
Venancio González ha probado que sabe escribir con gracia, con soltura; que es un escritor satírico tal como le piden nuestra lengua y nuestra raza. [...]

Venancio González tiene siete mil veces razón para poner en ridículo los versos malos de la nobleza [...]

En resumen, Venancio González, contra el sentir de Cañete, es un escritor correcto, fácil, gracioso y franco, que tiene dentro de sí un hombre noble, valiente, de buena fe, y un crítico de gusto delicado.

\section{Polémica $3^{\text {a }}$ : con los Fernández Shaw}

Consecuencia de la polémica con Cañete, le salió a Valbuena otro blanco para sus censuras en Fernández Shaw. Carlos Fernández Shaw había nacido en Cádiz en 1865 y a la altura de 1883, cuando la polémica con Cañete, tenía 17 años y había acabado de llegar a Madrid con algunos versos y mucha ilusión por conquistar fama en el mundillo literario. Publica en 1883 un librito de Poesías y al año siguiente, un largo poema titulado El defensor de Gerona. El joven poeta es prologado y apadrinado por don Manuel Cañete ${ }^{14}$. Visto lo cual, Antonio de Valbuena toma varias composiciones del joven Fernández Shaw como objeto de sus artículos.

Las primeras noticias las tenemos en los Ripios Vulgares, donde dedica nada menos que tres capítulos al poeta gaditano, el XIII, el XIV y el XV. Como era tan joven el poeta, no tenía Valbuena muchos datos a los que acudir para sus comentarios y censuras, por lo que lo que más resalta es el sonsonete de llamarle joven e incauto, señorito, en un caso palomino aturdido, y en los capítulos XIV y XV se dirige a él llamándole "amado Teótimo"" nada menos que en treinta y dos ocasiones. El primer capítulo (el XIII) dedicado a Fernández Shaw empieza así:

Pues este era un joven, muy joven...

${ }^{14}$ Leemos esta información en Un poeta de transición. Vida y obra de Carlos Fernández Shaw (1865-1911), obra de su hijo Guillermo FERNÁNDEZ-SHAW, Madrid (Gredos) 1969, pp.58-63.

${ }^{15}$ Este "amado Teótimo", como reconoce el mismo Valbuena la tercera vez que así le llama, es el "interlocutor" al que se dirige continuamente el libro de lecturas tan conocido y editado El Amigo de los Niños, del francés Abate Sabatier, traducido al español por D. Juan de Escóiquiz, publicado en Madrid por Casa Editorial Calleja. Ese es sin duda su origen inmediato. Pero en un escritor como Valbuena, que hizo todos los estudios eclesiásticos, no hay que descartar también las reminiscencias de la $I I$ Epístola de San Pablo a Timoteo, donde el apóstol utiliza una expresión semejante, o el inicio de los Hechos de los Apóstoles, donde San Lucas se dirige igualmente a un interlocutor llamado Teófilo. 
$Y$ tan joven y ya tan... mal poeta!

que desde luego cayó bajo la protección de don Manuel Cañete.

El cual don Manuel [...] le escribió un prólogo, o cosa así, para el primer tomito de versos, diciendo que estos eran sublimes y otras cosas...; en fin, lo que puede decir un académico del trapío de don Manuel; lo contrario de la realidad.

En trueque de lo cual, el joven diz que asegura que don Manuel es el poeta menos pedestre y de más vigorosa y alta inspiración de cuantos han invocado a las musas.[...]

El joven se llama Carlos Fernández, para servir y alabar a Cañete. Fernández y otro apellido que unos pronuncian sa y otros so, pero que yo no sé a punto fijo cómo se pronuncia.

Le afea después Valbuena varios defectos o ripios, uniones violentas de sonidos, adjetivos mal utilizados, "epítetos dislocados"... En el capítulo XIV de estos Ripios Vulgares le critica su obra recién publicada con el título de El defensor de Gerona, de la que Valbuena empieza diciendo que "está regularmente impresa, en buen papel y, además, es muy mala". Poco después le añade: "tú no eres poeta, ni de muy pocas facultades, ni de ninguna, ni poeta español, ni francés, ni nada más que un versificador mediano" [...] "no eres poeta ni podrás serlo nunca. Podrás ser, si te aplicas, regular estudiante de Derecho, y con el tiempo, regular, nada más que regular, abogado; pero poeta, no, por aquello de que quod natura non dat, Salamantica non prestat". Le remacha, algo más adelante: "Con que ya puedes convencerte, amado Teótimo, de que no eres poeta, y de que no sirve que te aplaudan alguna vez en el Ateneo diez o doce manos femeniles". En los defectos de los versos le recoge palabras disonantes, adjetivos poco apropiados, expresiones oscuras, aparentes incoherencias. Y dedica también el capítulo XV a Fernández Shaw, ahora con la disculpa de que en vez de retirarse de la poesía anuncia en La Correspondencia que va a hacer otro recital "en el casino de los militares". Los versos elegidos son también los del poema El Defensor de Gerona, y los reparos vienen a ser los mismos que en casos anteriores.

En conjunto puede decirse que aunque le dedica mucho espacio, no es con Fernández Shaw con quien más se ensaña Valbuena, probablemente porque no hay motivo, también porque su escasa trayectoria vital no da pie a censuras sobre su vida, hechos, pensamientos, etc. Y más bien parece elegir a este poeta como blanco de sus ripios por haber sido 'apadrinado' por Manuel Cañete. 
Así lo interpretó también la familia de Fernández Shaw en la biografía que mucho tiempo después sacan del escritor. Es el hijo, Guillermo Fernández Shaw, quien escribe el libro Un poeta de transición. Vida y obra de Carlos Fernández Shaw, y son los nietos quienes, al morir el padre, presentan el libro, que sale a la luz en 1969, en la editorial Gredos. Cuando llega a este suceso de la vida del padre, su hijo Guillermo, que es un incondicional admirador del padre, va contando cómo Carlos Fernández Shaw, al ir adquiriendo fama con sus versos, va empezando a ser envidiado; y a esa envidia atribuye alguna crítica negativa en la prensa. A ello añade el hijo la defensa de Manuel Cañete, "la máxima autoridad en materia de crítica literaria y de investigación" en aquel momento, en palabras de Guillermo Fernández Shaw: ¡Buena la ha armado Cañete! ¿Para qué quieren más los "apasionados censores"? A los envidiosos que va encontrando Carlos en su camino se unen ahora los enemigos de Cañete, que son incontables. El austero crítico se ha hecho famoso por sus severidades; y es lógico que se enzarce constantemente en polémicas nada gratas. No hace todavía un año que entre don Manuel Cañete y don Antonio de Valbuena se han cruzado en la Prensa frases muy molestas, a cuenta de una sección que Valbuena cultiva en El Progreso con el título de "Ripios aristocráticos". Ha fustigado el desenfadado cronista varias obras del marqués de Valmar, del marqués de Molins, del conde de Cheste y de otros Académicos; y Cañete en La Época ha salido en su defensa, calificando de groseros e insulsos los escritos vertidos por Venancio González, que es el seudónimo de Valbuena. Y la réplica de este -que ha sido leída entre risotadas en los cafés- pone a don Manuel Cañete "como digan dueñas". [...] Todo esto ha ocurrido en el año 83; de modo que, al encontrarse ahora, en el 84, con que don Manuel apadrina las obras de Fernández Shaw, transforma sus "Ripios académicos" en "Ripios tiernos" y arremete con ímpetu inconcebible contra Carlos, por el pecado de haber sido apadrinado por Cañete.

Esta es la explicación que el hijo da sobre las censuras que Valbuena vierte contra su padre Carlos Fernández Shaw. Tras lo cual le dedica un párrafo a esas críticas de Valbuena: Y aquí tenemos al autor de El Defensor de Gerona sometido a las ingeniosidades de don Antonio de Valbuena. Comienza este por llamar a Carlos "amado Teótimo" y por burlarse de sus apellidos con tan poca gracia como evidente exceso de mala educación. Demostrada así su intención de agraviar, pierden valor los ataques que va dirigiendo a distintos pa- 
sajes del poema: la aplicación inadecuada de algún adjetivo, el empleo de un verbo poco corriente, la repetición de un vocablo que da indudable vigor a la frase y la imagen poética que puede haber sido creada con más o menos acierto, son examinados con lupa de aumento por este Venancio González, que no duda tampoco en ridiculizar otra vez a Cañete, ni en decir, desvergonzadamente, que todos los Académicos son unos alcornoques.

\section{Polémica $4^{\mathrm{a}}$ : con Francisco A. Commelerán, 1886}

Sin duda, los comentarios laudatorios de Clarín, de febrero de 1885 (antes vistos), y otros que iba recibiendo, le animaban a seguir su labor, y Valbuena se iba creciendo y afianzando en sus críticas contra personajes tan importantes como los aristócratas. Ahora va a dar un paso más, como ya venía anunciando.

En 1884 había publicado la Real Academia Española de la Lengua la $12^{\mathrm{a}}$ edición de su diccionario, y el 11 de mayo de 1885 inicia Valbuena en Los Lunes del Imparcial una colaboración con el título de "Fe de erratas del diccionario de la Academia". Esta colaboración fue larga, duró hasta 1888, son 105 artículos, que fueron recogidos en 4 tomos, más de mil páginas en total, que lograron hasta una $4^{\text {a }}$ edición.

En la Fe de erratas Valbuena iba analizando, criticando, censurando los 'errores' que él veía en el Diccionario oficial. En general, se centra más en la microestructura o definiciones; pero también acude a menudo a la macroestructura, y censura la inclusión de palabras que no deberían estar o la no inclusión de palabras que sí deberían figurar.

Estos artículos de Los Lunes del Imparcial fueron llegando al gran público y creaban tanto malestar en unos como regocijo en otros $^{16}$. Quien mejor nos informa de ello es el mismo Valbuena en el prólogo a la publicación del tomo I: Cuando empecé a escribir los artículos, ni pensaba que fueran tantos, ni creía que hicieran tanto bien ni que alcanzaran tan unánime favor del público. Comenzaron por despertar en personas ilustradas la curiosidad de examinar el Diccionario, siendo el inmediato resultado de este examen la publicación de algunos trabajos muy apreciables contra el desventurado librote académico.

16 "Lo cierto es que Valbuena, con su insistencia, consiguió atraerse la atención pública [...] Se desarrolló viva polémica en los periódicos de todo signo" (Zamora Vicente, ob. cit., p.519). 
Cita luego seis trabajos en que otros escritores atacan al diccionario y continúa: La primera idea que tuvieron, idea como suya, fue demandarme por injurias a la Academia, corporación aprobada por el Estado; más como al oír yo la noticia me eché a reír, desistieron de tal propósito. Dieron luego notas e instrucciones a un catedrático de Instituto, Comelerán (sic) $)^{17}$ y este publicó en un periodicucho quincenal y malévolo, unos cuantos artículos bajo el epígrafe alarmante de "Crítica demoledora", pero por más que gritó y aulló y dijo desatinos, nadie le hizo caso.

De hecho, Valbuena no contestó a Commelerán más que con una alusión al final del cap. X, de 'Fe de erratas', p.106, en que dice: Cuentan de un escritor insigne, que habiendo recibido una carta en que una señora le censuraba un libro y empezaba diciéndole: "Es usted un ijnorante", no la contestó más que estas palabras: "Señora, ignorante se escribe con g". Una contestación análoga merecería el 'sabio' susodicho, si alguna mereciese".

$\mathrm{Y}$ en una nota a la publicación en libro (Fe de erratas, tomo I, p.9), añade Valbuena: Como la ignorancia y el furor son tan amigos, enfurecióse tanto y de tal modo llegó a perder la brújula este pobre hombre, que se disparaba ya contra mí en esta forma: “¿Por qué se guarda las razones que no puede aducir contra nuestro anterior artículo?...". Él se lo decía todo. Y todo por despecho, porque no le quise contestar más que dos palabras al fin del artículo $X$, sin acusarle siquiera de no emplear el talento que no tiene ${ }^{18}$.

Tampoco Commelerán debió de quedar muy tranquilo ante esta polémica con Valbuena. A. Zamora Vicente, en La Real Academia Española (p.532), recoge en nota: La abundante colaboración de F.

${ }^{17}$ Francisco Commelerán Gómez (1848-1919), catedrático de latín en el Instituto Cardenal Cisneros de Madrid y autor de varias obras de lengua: Gramática comparada de las lenguas castellana y latina (1889), Diccionario latino (1886), Lengua latina: autores sagrados y profanos. Ingresó en la RAE el 25 de mayo de 1890, tras ganar a Galdós. Su discurso de entrada se tituló "Leyes que regulan las transformaciones fonéticas en castellano". Valbuena siempre lo despreció y Clarín "se rasgó las vestiduras contemplando cómo el oscuro latinista Francisco Commelerán derrotaba a Pérez Galdós en la elección para una vacante de numerario" (J. Ma Martínez Cachero, en la Introducción a su edición de Palique, de Clarín, p.35). También nos aporta información sobre Commelerán A. ZAMORA VICENTE, La Real Academia Española, p.177).

${ }^{18}$ Este desprecio o desinterés por Commelerán es en Valbuena más aparente que real, pues en sus obras posteriores sigue sacando a relucir en muchas ocasiones siempre para criticar- el seudónimo de Commelerán, Quintilius. 
Conmelerán a favor de la Academia y en réplica a las afirmaciones de Valbuena, ante el riesgo de la fugacidad (y subsiguiente olvido) de la noticia periodística, fue recogida por su autor en edición no venal, hoy librillo de muy difícil hallazgo: Francisco Conmelerán, El Diccionario de la Lengua Castellana por la Academia Española. Colección de artículos publicados en La Controversia y El Liberal, en contestación a los que en El Imparcial ha dado a luz Miguel de Escalada contra la duodécima edición del Diccionario de la Real Academia Española por Francisco Conmelerán (Quintilius). No se vende. Madrid, Imprenta de A. Pérez Dubrull, Flor Baja, 22, 1667.

\section{Polémica $5^{\text {a }}$ : con Manuel Silvela, 1886}

Valbuena seguía su larga serie de artículos en periódico tan prestigioso como El Imparcial, y no solamente iba creciendo su fama sino que también él mismo se iba creciendo ante las críticas y críticos que le atacaban. Cuenta Valbuena su polémica con Silvela enlazándola con la anterior. Como a Commelerán nadie le hizo caso -ironiza-, la Academia buscaba una solución: Pasaban semanas y meses. El Imparcial seguía publicando mis artículos, y todo el mundo continuaba riéndose de los académicos y de la Academia. Había que hacer algo. El concejo de la calle Valverde ${ }^{19}$ seguía reuniéndose todos los jueves, sin que a ninguno de sus miembros se le ocurriera una idea salvadora. Por fin, uno de los más hinchados de entre ellos, el Excmo. Sr. D. Manuel Silvela ${ }^{20}$, alardeando de su influencia cerca de El Imparcial, se brindó a defender la obra de sus hermanos... y cubriéndose la figura bonachona y un tanto apavada con la vulgar careta de "Juan Fernández" "21 y sintiéndose como un desdichado al afirmar que no era académico, escribió hasta tres cartas con el intento de desfacer los agravios por mí inferidos al malaventurado libro. (Fe de erratas, pp.6sss.).

${ }^{19}$ En esta calle estaba el edificio de la Real Academia de la Lengua Española, hasta que en 1894 la trasladaron a la calle de Felipe IV. En alguna ocasión Valbuena, en vez de Valverde dice Va-al-verde, en son de burla de los académicos, a los que tanto criticó.

${ }^{20}$ Manuel Silvela, nacido en 1830, era académico desde 1871. Abogado y buen orador, fue diputado en varias legislaturas. También fue alcalde de Madrid, consejero de Estado, ministro en varias ocasiones, senador vitalicio. Colaboraba constantemente en periódicos con el seudónimo de Velisla. Murió en 1892. (Para más información, ver A. Zamora Vicente, ob. cit. p.215).

${ }^{21}$ Seudónimo que usó Silvela en su polémica con Valbuena. 
Tenemos así encuadrada la polémica entre Valbuena y Silvela. Este enfrentamiento consta de cinco testimonios publicados en $\mathrm{El} \mathrm{Im}$ parcial: tres cartas de Silvela y dos artículos de Valbuena, y tuvo el desarrollo siguiente: Valbuena empezó sus artículos contra el diccionario el 11 de mayo de 1885 y Silvela escribe la primera carta el 1 de noviembre de 1886, a los 17 meses y medio. A los quince días le contesta Valbuena, el 15 de noviembre, con el artículo XXIV de su Fe de erratas. Al lunes siguiente, 22 de noviembre, escribe Silvela la segunda carta que titula "Fin de una polémica". Valbuena no le hizo caso y le contesta al lunes siguiente, 29 de noviembre, con el capítulo XXV. Aún escribió Silvela una tercera carta, pero la polémica se hizo tan dura que el Sr. Ortega Munilla, director de "Los Lunes" de El Imparcial, tomó parte en el asunto e impidió a Valbuena que contestase. Vamos a seguir más de cerca esta polémica.

El capítulo XXIV de la Fe de erratas es la contestación a la primera carta de Silvela. Valbuena se ve obligado a tratarle con el seudónimo Juan Fernández, aunque desde el primer momento supo que era Silvela. Y empieza:

Sr. D. Juan Fernández.

Muy señor mío y dueño: por ser vos quien sois, es decir, porque sé que es usted un encopetado académico de la lengua, según lo han dicho La época $y \mathrm{El}$ correo $y \mathrm{El}$ progreso y otros periódicos y todo el mundo, voy a contestar a la carta de usted del otro lunes, y no del otro jueves, de la que a su tiempo me dio traslado nuestro común amigo el Sr. Ortega Munilla. Pura cortesía nada más, que no necesidad de defenderme contra la tal epístola, puesto que apenas... y este apenas también lo pongo por cortesía, apenas hay en ella nada de sustancia.

Valbuena afea a Silvela que se metiese a tal empresa, le refuta los argumentos y le comenta sus diversas frases, según los casos. La contestación de Silvela no se hizo esperar. Si Valbuena no publicó la respuesta hasta pasadas dos semanas, Silvela contestará al lunes siguiente. Acaso por su afán de quedar por encima del crítico y sin duda para evitar nuevos y violentos ataques, titula su segunda carta "Fin de una polémica". ¡Bueno estaba Valbuena para aceptar el "plan Silvela"! Y ahora sí, a los ocho días, es decir, al "Lunes" siguiente, contesta con el artículo XXV, más fuerte que el anterior, más despiadado y más largo: Tiene usted unas cosas, D. Manuel... Sin vela ${ }^{22}$ en este entierro

${ }^{22}$ Valbuena tenía que tratar a Silvela bajo el seudónimo de Juan Fernández con el que Silvela publicaba los artículos. Al escribir aquí Sin vela tras el D. Manuel, 
académico, empeñose usted en tomar en él alguna parte, y ha concluido usted por ser el difunto.

Como a Valbuena, en la primera contestación, se le hubiese escapado un 'D. Manuel' (en vez de 'Juan Fernández'), Silvela en la segunda carta se llamó "Juan Manuel Fernández" para obstaculizar la identificación, y sigue acuciando a Valbuena para que haga él las definiciones del diccionario, ya que tanto las critica. Nuestro crítico le contesta que él no cobra -como los académicos- por hacer diccionarios, pero además: Ya he dicho que haré un diccionario, si Dios me da salud, pero le haré cuando pueda y quiera, y no cuando a usted se le antoje; por de pronto déjeme usted acabar de desacreditar el de ustedes.

Le echa Valbuena en cara que con sus chistes y demás palabras deje sin contestar a los fallos y enmiendas puestos al Diccionario:

¿Por qué no defiende usted aquello de que el lloro de las niñas recién nacidas tira más a la "e" que a la "a", al contrario del de los niños ${ }^{23}$, o aquello otro del "grodetur" o cualquiera otro de los mil disparates que produjeron los difuntos de la letanía que rezaba usted el día pasado, comenzando por Luzán y acabando por Escosura?

Llevo a estas horas señalados en el Diccionario, entre sobras y faltas y disparates, sobre mil doscientos. De ellos se contenta usted con defender once. Supongamos que en esos once tuviera usted razón. Siempre quedarían firmes mil ciento ochenta y nueve, que para las dos primeras letras y principio de la tercera me parece que es una cantidad respetable.

Y acaba el artículo:

Por último me dice usted que no me conoce "ni de vista ni bajo ninguno de los nombres que he usado”. ¡Cruel! ¿Y me lo dice usted así sin preparación y a boca jarro?... Ah, crea usted, D. Manuel, que desde que lo he leído estoy inconsolable. Porque ¿de qué me sirve ha-

cualquier avispado leía ya Manuel Silvela. Las ingeniosidades de Valbuena no tienen límite.

${ }^{23}$ Se refiere Valbuena a la definición que daba la $1^{\mathrm{a}}$ edición del Diccionario de la Real Academia, de 1739, que decía de la letra "A": "En el orden es la primera, porque es la que la naturaleza enseña al hombre desde el punto de nacer para denotar el llanto, que es la primera señal que da de haber nacido; y aunque también la pronuncia la hembra, no es con la claridad que el varón, y su sonido, como lo acredita la experiencia, tira más a la E que a la $\mathrm{A}$, en que parece dar a entender que entran en el mundo como lamentándose de sus primeros padres Adán y Eva. Permanece tan propia en el sujeto que, aunque nazca mudo, siempre la pronuncia...". 
ber recibido y estar recibiendo mil parabienes por mi tarea de desasnar académicos, si no me conoce, o por lo menos, faltando a la verdad, asegura que no me conoce un fantasmón risible que ni siquiera se atreve a decir cómo se llama?

Otras voces se oyeron también en esta polémica. Por la importancia de los participantes, entresacamos dos, la voz de Clarín y la de Rodríguez Marín. De la primera contestación a Silvela, le dice Clarín a Valbuena en carta del 17 de diciembre de 1886 (recogida por F. de la Cuesta ${ }^{24}$, p.31): Ayer leí el (artículo) de V. que ya esperaba y me gustó mucho [...] Silvela siempre me ha cargado mucho porque es pedante, y quiere hacer gracia sin ser gracioso, pero no tengo a mano nada suyo ni lo recuerdo. Además es un señor que ya no da juego.

Y Rodríguez Marín le decía a Valbuena el 17 de diciembre de 1886 (F. de la Cuesta. p.29): Encárgame también mi amigo (él mismo) que haga a $V$. presente el grande regocijo con que lee y saborea los artículos de $V$. eminentemente patrióticos, digan lo que quieran los Juanes $^{25}$ a quienes punzan.

Y el mismo Rodríguez Marín, el 5 de marzo de 1887, dice en carta a Valbuena que le envió un ejemplar del $n^{\circ} 47$ del Centinela de Osuna en que puso un artículo para "Sin-vela" ${ }^{26}$ titulado "Palmetazo a Palmetilla".

A la tercera carta de Silvela, nuestro crítico ya no pudo contestar en El Imparcial. Pero nos da las noticias en el prólogo a la publicación en libro de su Fe de erratas:

A esta tercera carta ya no pude yo contestar en El Imparcial porque D. Manuel invocó allí sus derechos de ciudadanía liberal, para librarse de nuevos azotes.

Verdad es que esta tercera carta, que D. Manuel no debió escribir, ni mejoraba su situación en nada, ni destruía ninguno de mis anteriores argumentos. $Y$ así debió de comprenderlo el ilustrado director de los "Lunes de El Imparcial” cuando creyó necesario ponerla un preámbulo diciendo que D. Manuel era un respetable hombre público, que yo le había tratado con demasiada acerbidad, que como

\footnotetext{
${ }^{24}$ Recoge estas cartas Filemón de la Cuesta en Valbuena y sus poesías, Diario de León, 1944.

${ }^{25}$ Alude a Silvela, que firmaba con el seudónimo de Juan Fernández, como venimos viendo.

${ }^{26}$ En nota anterior se aclaró lo de Sin-vela.
} 
político había desempeñado altos puestos con general aplauso... todo lo cual quizá no fuera de lo más a propósito para probar que el Diccionario es bueno y que D. Manuel salió airoso en su empresa; pero probaba indudablemente los buenos sentimientos y la generosas compasión de mi particular amigo el Sr. Ortega Munilla, que, viendo al Sr. Silvela tan descalabrado y maltrecho, quiso recogerle y vendarle cariñosamente las heridas, y presentarse así entrapajado a la conmiseración pública. (pp.10-11).

De esta manera acabó la gran polémica, pero no la ola de indignación académica, que fue más duradera. En vista del poco resultado de las defensas de Silvela, los académicos -cuenta Valbuena- organizaron una nueva campaña, con varios artículos que aparecieron bajo diferentes firmas y en distintos periódicos a un tiempo, para meter ruido y decir que su crítica no era justa ni aceptable, y que Silvela le había derrotado. De manera que, según Valbuena: Organizado de este modo el servicio, comenzó entre los académicos la faena más desesperada de que hay memoria, y se les vio por espacio de dos meses corriendo de acá para allá, febrilmente agitados por la soberbia y el despecho, reuniéndose todas las noches, rebuscando textos, leyendo libros que no habían visto nunca, urdiendo mentiras y tramándolas luego con necedades para publicar cada semana en cuatro o cinco periódicos otros tantos artículos escritos sin más numen que la ira...(Fe de erratas, pp.13-14).

Estas críticas y polémicas no amilanaban al crítico; más bien lo que hacían era enardecerle, confirmarle en la valía de sus artículos, porque se hablaba de ellos, porque era muy leído, porque llegaba cada vez a mayor público y los libros se publicaban mejor, se vendían más. "La ola pasó, pero fue terrible" diría más tarde el crítico ${ }^{27}$. No tuvo Valbuena ningún otro momento tan intenso de lucha. Sus obras posteriores serán mejores, peores, o simplemente semejantes, pero no levantaron una ola tal de tan resonantes y disonantes voces. Así lo confirma también Alonso Zamora Vicente (1999) al hacer la historia de La Real Academia Española (p.532): "El clima de agria controversia que Valbuena despertaba llegó a los más apartados rincones de la Península. Prueba de ello es la aparición de publicaciones, hoy ignoradas, donde modestos profesores o aficionados salían a escena, ya a favor, ya en contra de unos o de otros, generalmente con un claro deseo de lucimiento personal". Y esa es la impresión que nos dejan las pala-

\footnotetext{
${ }^{27}$ Prólogo a Fe de erratas, en forma de libro, p.12
} 
bras de Julio Casares, en su Crítica efímera ${ }^{28}$, treinta años después de esta polémica, cuando hacia 1917 y 1918 polemiza también duramente con Valbuena, y nos va regalando expresiones como estas: "viene amargando la vida a varias generaciones de académicos" (p.183), "el celebrado autor de los Ripios, que vuelve ahora al palenque sin el ingenio y gallardía de la juventud y con los mismos arreos, rudimentarios y maltrechos, que lució hace veinte o treinta años" (p.216), "terrible censor de la Fe de erratas" (p.235), "lleva casi medio siglo repartiendo palmetazos" (p.240), "aún perdura el recuerdo de los primeros Ripios y de las carcajadas con que fueron acogidas las agudezas de la Fe de erratas" (p.242).

\section{Polémica 6 ${ }^{\mathrm{a}}$ : con Menéndez Pelayo, 1888}

Hablar de 'polémica' de Valbuena con Menéndez Pelayo es ser poco exigente con el término 'polémica'. Probablemente, sí le hubiera gustado a Valbuena, pero no logró obtener respuestas del ilustre sabio santanderino. La que llamamos 'polémica' con Menéndez Pelayo la leemos en el capítulo II de los Ripios Académicos.

Acabada la $\mathrm{Fe}$ de erratas en 1888 (no porque llegara censurando al final del diccionario, -solo llegó a la letra "e"- sino sin duda por cansancio, o por cambiar ya de tema, después de cinco años), publica Valbuena una obra que venía preparando y anunciando desde hacía mucho, los Ripios Académicos, es decir, las críticas de los versos y prosas de autores que eran de la Real Academia Española de la Lengua.

Los capítulos 1 y 2 los dedica a Marcelino Menéndez Pelayo. En el cap.I leemos:

Al repartir yo a los académicos el pan espiritual de la corrección, quiero imitar a los dominicos, siguiendo como ellos el ejemplo de los ángeles, por lo cual voy a comenzar por Marcelino Menéndez. Pelayo, que en el refectorio de la calle de Valverde es el más joven. $[\ldots]$

Pero entiéndase bien, que solo en la edad, es Marcelino inferior a sus compañeros; pues en todo lo demás, incluso en hacer versos malos, está a la misma altura que otro cualquiera.

Le critica un libro de poesías: le censura el prólogo que le puso Valera, le censura la larga dedicatoria, le censura expresiones cacofónicas como "inviolada lira", le censura la adjetivación (profanado canto, venal incienso, opresores viles, ardido esposo de Jimena), le

\footnotetext{
${ }^{28}$ Crítica efímera, tomo I.
} 
censura el léxico (numeroso acento, la Némesis plebeya, virgen mancebo laletano), le critica los hipérbatos (vertieron las sagradas / de Mnemosine hijas). En el capítulo segundo de Ripios Académicos sigue comentando versos de Menéndez Pelayo. Si los del capítulo anterior eran de antes de ser académico, los versos que le censura en este capítulo II son versos compuestos siendo ya académico. Pero las censuras son semejantes. Hasta que descubrimos -en la pluma de Valbuenalo que parece que fue una airada reacción de Menéndez Pelayo.

$Y$ no vale -dice Valbuena- enfadarse, no, ni ponerse furioso, como creo que te pusiste hablando de mí una vez que, accionando sin gracia con los dedos abiertos, y trabándote mucho la lengua decías:

- No escribiré la historia de la sátira en España, por no nombrarlo; y se fastidiará, porque yo dejaré treinta volúmenes y él dejará cuatro libelos...”

Lo cual no sienta bien a Valbuena, que le contesta en este capítulo II de Ripios Académicos que venimos comentando:

No, eso no conduce a nada: sosiégate, y deja todos los volúmenes que quieras; pero convéncete de que más te valdría no dejar este de los versos [...]

En fin, créeme, apreciable joven, que solo por tu bien te lo digo: quema este libro de las Odas, elegías, tragedias y demás, y no vuelvas a meterte a poeta.

Hazlo por tu fama.

Porque en prosa escribes bastante bien, dicho sea en obsequio a la virtud de la justicia, mi amiga y compañera inseparable.

Pero los versos los haces muy malos.

$Y$ muy ridículos.

Y sobre Menéndez Pelayo vuelve Valbuena en el capítulo XXII de la misma obra. En este caso le 'analiza' el libro Las cien mejores poesías líricas de la lengua castellana. En dicho capítulo va comentando esas cien poesías, una a una, si está bien o mal elegida para figurar en un libro con 'las cien mejores poesías líricas'. Reproducimos las primeras líneas y las últimas de dicho capítulo XXII.

Con un título indiscretamente presuntuoso y con un gusto candorosamente depravado ha reunido Marcelino Menéndez $z^{29}$ en un librejo cien poesías líricas.

${ }^{29}$ La costumbre de prescindir, maliciosamente, del segundo apellido la repite Valbuena también con Emilia Pardo Bazán, a la que llama repetidamente Doña Emilia Pardo. 
A lo menos así las llama él; aunque luego resulta que en realidad algunas no son líricas, y muchas no son poesías.[...]

En fin el caso es que la colección de cien poesías líricas de nuestra lengua, que con un título más modesto, y escogida por un literato de buen juicio y buen gusto, hubiera resultado un libro precioso, titulada fanfarronamente y escogida al revés por el académico Marcelino, ha resultado una chapucería.

En Valbuena nos sorprende su ligereza, su crítica chocarrera, sus bufonadas, sus salidas del tema yéndose al ámbito personal, pero cuando hace acotaciones lingüísticas o literarias a menudo suele tener razón. Y ya al joven Menéndez Pelayo se atrevió a decirle que escribiera en prosa pero no en verso. De hecho, en sus Ripios Académicos criticó versos de los académicos Menéndez Pelayo, Alejando Pidal y Mon, Manuel Cañete, Aureliano Fernández Guerra, José Echegaray, Pedro Madrazo, Manuel Silvela, Juan Valera, Cánovas del Castillo, Mariano Catalina, Víctor Balaguer, Núñez de Arce y el Conde de Cheste, ninguno de los cuales ha pasado a la historia de la Literatura como grande ni siquiera como mediano poeta. $Y$ en cuanto a las críticas que Valbuena hace del Diccionario académico en su Fe de erratas, muchas de ellas lograban lo que pretendía: que cambiaran la definición, que quitaran esa palabra, que añadieran otra, que pusieran la acepción que él proponía. Alonso Zamora Vicente, al hacer la historia de la Academia (La Real Academia Española, 1999), y con su habitual ecuanimidad, dice:

Los Ripios debieron de ser muy leídos. Y es verdad que la Academia atravesaba un bache muy notorio. Habían entrado muchos políticos. La filología aparece en mantillas, en manos de personas aficionadas [...] A veces, el escalpelo de Valbuena peca de muy estrecho, de tener miras poco generosas y sin voluntad de entendimiento. Sin embargo, hay que reconocer que, en lo que se ciñe a los nombres y a las obras comentadas, no era una crítica puramente gratuita. [...]

Son numerosos los casos en que Valbuena lleva razón. [...] El aviso del crítico era, pues, muy útil. Pero la constante apelación enfurruñada, a veces violenta, aderezada con una ironía bastante burda, desautorizada al censor. [...]

Lo cierto es que Valbuena, con su insistencia, consiguió atraerse la atención pública. Nada podía halagar más su vanidad, su falaz sabiduría. Se desarrolló viva polémica en los periódicos de todo signo. Valbuena había ido dejando crecer su mal humor, su agresividad. 
Menudean los insultos a los académicos, etc. El crítico, al ver en la calle su lucha, se sintió feliz, crecido.” (I, 6). (pp.517-520).

\section{Polémica $7^{\mathrm{a}}$ : con Emilia Pardo Bazán, 1891}

Valbuena tuvo una permanente obsesión con Emilia Pardo Bazán, encontró en ella un continuo motivo de burlas. En un primer momento, la condesa emitió una muy medida opinión sobre Valbuena, pero después evitó toda pelea con el crítico.

En 1891 publicó Valbuena un libro de relatos titulado Capullos de novela. $\mathrm{Y}$ en setiembre de ese mismo 1891, en el $\mathrm{n}^{\circ} 9$ de su Nuevo teatro crítico, Emilia Pardo Bazán, en la sección de "Notas literarias", p.82ss., comienza a hablar de Valbuena: El nombre de este escritor, que se cuenta hoy entre los más leídos, que tiene su auditorio y sus partidarios acérrimos, y que es un favorito de la juventud (los muchachos entre quince y veinte se lo saben de memoria), suele tomarse como enseña de batalla contra determinadas personalidades literarias o políticas, y especialmente contra la colectividad de la Academia de la Lengua [...]. Si a esto se suman circunstancias especiales que en mí concurren, y que todo el mundo recuerda para mal en estos casos, se comprenderá lo difícil de mi posición cuando recibo un libro de Valbuena.

Pardo Bazán está aludiendo al ambiente enrarecido que ronda en torno a Valbuena y a su difícil relación con él. Y continúa la condesa: Recuerdo que en cierta ocasión dije yo a Miguel de Escalada: "Si V. viese el conjunto, el alma de los libros, como ve el pormenor y el elemento puramente formal, externo, sería $V$. un criticazo." $Y$ hoy tengo que añadir, refiriéndome a Capullos: "Si en este autor correspondiese la importancia del contenido novelesco y humano, al encantador desafeite del estilo, al sabor neto y puro del lenguaje, tendríamos un cuentista y la promesa de un novelista de primera línea. Ya que no es posible afirmar esto por los Capullos, no omitamos que alguno de ellos -verbigracia: El bobo de la feria, o El caballo del diablo- es un dechado de naturalidad y frescura popular." Valbuena anuncia otras novelas: hasta que las publique, sea provisional este juicio.

Pardo Bazán intentó ser ecuánime con el crítico. Valbuena, sin embargo, no perdió ocasión de censurar a la novelista. En Agridulces políticos y literarios (pp.145-146) refuerza el argumento de otro crítico que habla mal de las novelas de Pardo Bazán. En el tomo I de Ripios Ultramarinos, sin venir muy a cuento y entre otras cosas, dice: 
Porque como la señora Doña Emilia Pardo Bazán, en ese Nuevo teatro crítico que escribe mensualmente, poco más que para su particular uso, creo que ha dicho que no veo apenas más que la superficie de las cosas, podía parecer que trataba de defenderme de ese cargo si hablara del fondo; y nada hay más lejos de mi ánimo que hacer semejante defensa.

No la necesito, a Dios gracias.

Pues ya se sabe que la buena de Doña Emilia dijo esa y otras cosas, contra lo que siente, para ver de congraciarse con los académicos, porque tiene el afán de ser académica.

$Y$, naturalmente, ha pensado: “QQué cosa más grata para los académicos puedo yo hacer que escribir algo contra Valbuena?... Por una cosa así han hecho académico a Comelerán.[...] (pp.99-101).

Y hacia el final de este mismo tomo I de Ripios ultramarinos, en artículo dedicado a Manuel Gutiérrez Nájera, aprovecha la ocasión para volver a atacar a la Pardo Bazán acusándola de plagio. En 1896 publica Valbuena su volumen $3^{\circ}$ de Ripios Ultramarinos. En el capítulo $\mathrm{X}$ y hablando de revistas literarias en Hispanoamérica y de lo poco que duran, añade: "Por cierto que el Teatro crítico de Doña Emilia murió al medio año no más de habérselo yo profetizado en el primer montón de Ripios Ultramarinos, y murió disparando flechas contra mí.” (pp.160-161). Y en el cap. XVI (p.276) insiste:

Se me dirá que parecidos disparates se publican en revistas y periódicos de España, y aun se me citará el ejemplo reciente de Doña Emilia Pardo Bazán, que acaba de matar una garduña al vuelo en el Blanco y Negro, y aun después de muerta se ensaña en describirla diciendo que medía tres cuartas de una punta a otra de las alas.

Pero el caso de Doña Emilia Pardo Bazán no vale para formar regla, porque tan ignorante como esta buena señora no hay nadie en España.

Ni aun en Academia [...]

De 1899 es Des-Trozos literarios, donde Valbuena se va viendo cada vez más obsesionado con la condesa de Pardo Bazán. En el capítulo IV alude a ella y a Pérez Galdós como "dos escritores genuinamente sosos". En el capítulo VI le dedica seis páginas a Doña Emilia y le sigue afeando varios deslices: "Es Doña Emilia Pardo, la inevitable Emilia, como decía Zorrilla, la que petrifica las lágrimas y enquista los pensamientos con la misma facilidad con que hace volar a las garduñas" (pp.64-65). El capítulo VIII lo titula "Cosas de Doña Emilia" y 
está todo él dedicado a comentar y censurar expresiones, palabras, textos de Pardo Bazán. Y vuelve Valbuena a afearle lo de las alas de la garduña: “¿Alas ha dicho Ud.?... ¡Dios mío!... Crea usted, Señora Doña Emilia, que, desde que se las puso Ud. a la garduña, en cuanto mienta usted las alas me echo a temblar, previendo un estropicio" (p.84).

Más adelante, en el mismo capítulo de Des-Trozos literarios (p.102 ss.) leemos:

O no ha de escribir Doña Emilia, o ha de errar, aun en las cosas más triviales y conocidas.

De manera que, para bien ser, se había de reformar el aforismo latino aquel que dice: Humanum est errare, para aplicársele más directamente a Doña Emilia, diciendo: Emilianum est errare.

Porque hay cosas en que ya no yerra nadie más que ella.

$Y$ los académicos, a lo sumo. [...]

Una señora que cree que inhibirse es... lo contrario de lo que es realmente y lo escribe así, y llama pena de daño a la pena de sentido, y viceversa, y cree que vuela la garduña y la presenta volando y aun la mide la longitud de las alas, y habla de la densidad de la temperatura..., y afirma que el sacerdote al imponer la ceniza dice quia pulvis eris... una señora que tales cosas escribe es académica por derecho propio.

Las últimas invectivas de Valbuena contra Emilia Pardo Bazán las leemos en Corrección fraterna, ya de 1910. Si recordamos que las primeras eran de 1893, nos suman casi veinte años de ataques del crítico a la escritora gallega. Titula "Emilianas" el cap.VIII de este último libro. Y en él le censura diversos aspectos de un artículo publicado por Pardo Bazán en Blanco y Negro, donde además del texto sale también un dibujo reflejando la escena, de "un ciego con una montera y una rapacina despeluciada y morriñosa, mientras a lo lejos se ve venir una señora que el dibujante querría que fuese $D^{a}$ Emilia, y ella también lo querría ser, pero no puede serlo, porque es una figura mucho menos gruesa que $\mathrm{D}^{\mathrm{a}}$ Emilia, más agentilada y más joven" (p.115). Le llama después varias veces "la señora Pardo" y acaba el capítulo:

Lo digo porque hace ya bastantes años escribió una novela que se titulaba Una cristiana, cuya protagonista, sin embargo, no era buena cristiana, sino pecadora, cuando menos de afición, y allí también un sobrino del marido de la cristiana, enamorado de ésta, la coge las manos y roza contra ellas su frente, sin que la cristiana las retire... 
Y todavía volverá la Sra. Pardo a pintar la misma escena en algún otro libro...

Porque $D^{a}$ Emilia es así.

Tiene poca inventiva; pero mala. (p.135).

Aún le dedica el capítulo XVII y último de Corrección fraterna a la condesa bajo el título "A doña Emilia. Donde se halle. (Carta de la garduña)", donde inventa una carta de una garduña a Emilia Pardo Bazán recordándole todos sus 'errores', sus lapsus, explicándole que no tiene alas:

¡Ay! No, señora, no: créame usted... ¿Qué más quisiera yo que tener alas? [...]

Tampoco usted las tiene; ni las materiales del ave, ni las metafóricas del genio. Pero usted, bien mirado, no las necesita...

¿Qué falta la ${ }^{30}$ hacen a usted las alas?... Usted es una señora y tiene dinero... Cuando la conveniencia o la vanidad se lo piden, o lo que es lo mismo, cuando a usted se la antoja, se pone en el tren expreso y se va a París de Francia en un periquete... Ojea usted sin zozobra los escaparates, porque como va usted bien vestida, vamos, con buena ropa, nadie desconfía de usted... Hace usted presa en Ozanam, en Montalembert, en Emilio Zola, en Melchor de Vogüe... y se vuelve usted a Madrid tranquilamente, trayéndose en el baúl las piezas a casa. Algún tiempo después pone usted a la venta el San Francisco... los Pazos de Ulloa, la Novela en Rusia... y tan campante. [...]

¿De modo que usted cree que el señorito me vio en el cielo?

... ¡Buenas y gordas!... Nunca subí allá, ni subiré... Y a usted le costará trabajo. Lo que es como siga usted escribiendo novelas naturalistas...

\section{Polémica $8^{\mathrm{a}}$ : con Manuel Gutiérrez Nájera, 1893}

Manuel Gutiérrez Nájera es mejicano (1859-1895), periodista, poeta, narrador. Utilizó el seudónimo de "Duque de Job" en sus crónicas periodísticas. Fundó la Revista Azul y tuvo gran importancia en el desarrollo del modernismo, del que fue un precursor. Como poeta fue muy celebrado en su país ${ }^{31}$, tiene influjos románticos de Bécquer y

${ }^{30}$ El laísmo en Valbuena fue permanente. Hasta tal punto estaba convencido de que era correcto el uso de "la" en el complemento indirecto femenino que en 1910 publicó un libro de 96 páginas titulado El La y el Le, haciendo acopio de múltiples ejemplos que acreditaran su doctrina.

${ }^{31}$ Ver el Diccionario de grandes figuras literarias, de J. MARTÍNEZ CACHERO, p.301. 
Musset y de la poesía mística española. Escribió también libros de cuentos.

A Gutiérrez Nájera dedica Valbuena íntegros los capítulos XIX y $\mathrm{XX}$ del tomo I de Ripios Ultramarinos y algunas alusiones en los capítulos anteriores. En estos capítulos nos enteramos de que Gutiérrez Nájera fue muy beligerante con Valbuena, a la vista de las noticias que Valbuena nos trasmite. Según las cuales, el mejicano había publicado en el periódico de Méjico El Partido Liberal "varios desahogos" contra los Ripios Académicos, y "cuatro artículos muy largos" contra los Ripios Vulgares. "El hombre -dice Valbuena- chilló, pateó, manoteó, se desesperó e hizo toda clase de figuras... tristes, por ver si a fuerza de visajes y de ahuecar la voz y decir palabrotas lograba que la gente se fijara en él; mas ni por esas. Yo no le contesté, y nadie le hizo caso". Y pasa después Valbuena (cap.XIX) a recoger y comentar las expresiones que Manuel Gutiérrez Nájera le dedica (Entresacamos solo lo de Gutiérrez Nájera):

Malgasta, pirateando en las letras sus no obvios saberes en el habla castellana, quien desvirtúa la bondad de éstos abajando la crítica a regateos gramaticales y pendencias ruines [...]

Sencillísimo es el procedimiento de Valbuena: arremete contra versificadores rematadamente malos, lo que no tiene gracia, sino cuando va sazonado con ingenio y cierta picardía de que él carece...

¿Qué saberes ha exhibido el Sr. de Valbuena en sus obras publicadas? Si por ellas hemos de estimarle, sabe gramática, bastante sabe del latín... y tiene cierta gracia truhanesca...

Ante estas acusaciones no se quedó impasible Valbuena. Él no conoce al mejicano, pero se lo han descrito y, basándose en su figura, se lo toma no poco a broma y le llama continuamente "Manolín" y "Manolito". En estos dos artículos que le dedica (el XIX y el XX, pp.235-265 del tomo I de Ripios Ultramarinos) se refiere Valbuena a Manuel Gutiérrez Nájera 24 veces con la denominación de 'Manolito' y 50 veces con la de 'Manolín'. Y ya el capítulo XIX lo comienza de esta manera: la fiesta...

¡Ea! Póngase usted en facha, Manolito, que es usted el mono de

Ahí le tienen ustedes.

No crean ustedes que es un muñequito de esos que saben decir papá y mamá, no: es un hombrecito. 
Pequeño, muy pequeño, de estatura de perro sentado; pero de movimientos solemnes, de ojos imperceptibles y de nariz cruelmente larga.

Yo no le he visto; pero así vendrá a ser por las señas que en una carta me han dado poco hace.

¿Qué, no les parece a ustedes demasiado hermoso?

¡Ah! Pues todavía añaden al describirle, que suele llevar con afectados modales en una mano el bastón, en la otra el puro, y además una flor en el ojal de la levita...

Ese es Manuel Gutiérrez Nájera o el Duque Job, dos nombres distintos y un solo mal escritor verdadero.

Va después desmenuzando las acusaciones que Gutiérrez Nájera le había hecho y tratando de ridiculizarlo, y acaba este capítulo:

Con que, adiós, Manolín: toma tila; no vuelvas a decir "deviene" lo que va a llegar, porque es un galicismo muy feo; no digas tampoco que "echo todo a barato", lo cual, a más de no ser verdad, es otro galicismo; ni llames a mi tono despectivo, como se dice en la Academia, sino despreciativo, como se dice en castellano; ni escribas inhumido por seco; ni defiendas trasposiciones como la del

“...... pomposo,

hospedador de pájaros cantores,

amante de esta costa, tamarindo",

ni vuelvas a hablar de dar coces cuando te refieras a las personas.

Porque cualquiera a quien tú trates de burro, te dirá:

Por mayor te respeto,

y en la cuadra te meto,

y la cincha te aprieto.

$Y$ hasta otro rato. (p.247).

El capítulo XX de Ripios Ultramarinos (Montón I), también dirigido contra Manuel Gutiérrez Nájera, empieza:

Ya han visto ustedes a Manolín disfrazado de duque y escribiendo en prosa.

Verán ustedes ahora a Manolín con su propio traje de Gutiérrez Nájera, escribiendo en verso.

Les he dicho a ustedes que de ambos modos es Manolín muy mal escritor, y voy a probarlo.

Para ello, habiendo ya saboreado a Manolín al natural, se lo voy a servir a ustedes ahora con patatas. 
Es decir, con ripios.

Le comenta en este capítulo una composición "A Salvador Díaz Mirón" y va verso a verso, afeándole lo que el crítico dice que son adjetivos mal colocados, expresiones incoherentes, uniones cacofónicas de sonidos, palabras innecesarias o ripiosas, cambios en el orden de elementos en la frase, construcciones gramaticales ininteligibles. Y acaba el capítulo y sus ataques a Gutiérrez Nájera.

\section{Polémica 9a: con José Alemany, 1918}

Esta es, de las aquí analizadas, la polémica menos polémica. De ella tenemos un testimonio del 28 de julio de 1918, en recorte del periódico ¿El Imparcial? Es un artículo de Valbuena, en el que contesta a otro de D. José Alemany ${ }^{32}$, que ponía pegas a uno anterior de Valbuena. Según se deduce de los datos que recoge el crítico, las intervenciones fueron así: Valbuena publica el 21 de junio de 1918 un artículo en El Imparcial sobre los prefijos ex- y es-. A dicho artículo le hace ciertas observaciones en el mismo periódico D. José Alemany el 16 de julio de ese mismo 1918. Y el 28 de julio del mismo año le contesta Valbuena en el artículo que ahora estamos comentando.

$\mathrm{El}$ artículo o motivo de la polémica parte de las interpretaciones sobre la sí o no diferencia de los prefijos ex- y es-, pero Valbuena incluye después otras cuestiones. Si Alemany había escrito "El error del Sr. Valbuena estriba en creer que es y ex son prefijos de distinto origen", Valbuena le contesta: "Yo no he dicho una palabra del origen de esos prefijos. En ninguno de los dos artículos dedicados a exponer y censurar la irracional ortografía de la Academia me he metido para nada con el origen del es y del ex. He señalado el origen de algunas palabras, pero no el de los prefijos. De manera que ese error no puede imputárseme". Y sigue Valbuena: Lo que he dicho y digo de esos dos prefijos es que tienen distinto uso, naturalmente porque tienen distinto significado. He dicho que "el ex tiene ya en nuestro idioma uso universal y constante, significando cesación, privación, despojo, y que en ningún otro sentido debe ser usado". Y también he dicho y sostengo que el ex tiene distinto sonido que el es, pese a las académicas argu-

32 José Alemany (según A. Zamora Vicente, ob. cit., p.206) fue catedrático de Griego en la universidad de Granada y de Madrid. Hizo estudios sobre la formación de palabras en español, se le encargó la edición de un Diccionario Manual, publicó Estudio elemental de Gramática histórica de la lengua castellana, e hizo varias traducciones y ediciones críticas de nuestros clásicos. Ingresó en la RAE el 14 de marzo de 1909 con un discurso titulado "Orden de las palabras en relación con el orden de las ideas”. Había nacido en Cullera, (Valencia) en 1866 y murió en Madrid en 1934. 
cias de mi amigo el Sr. Alemany y que ni el distinto sonido ni el distinto significado son de ahora, sino que tienen cuando menos, siglo y medio de uso innegable, pues en el reinado de Carlos III compuso un EX-JESUITA el soneto que empieza: "No me llaméis ex por compasión...", buena prueba de que ya entonces eran populares el prefijo ex y su actual significación privativa.

Valbuena remata el artículo refutando "brevemente algunos de sus errores" [del Sr. Alemany], como "el de confundir el ex y el es, diciendo que valen lo mismo"; "otro error es defender como bueno el uso trocado de los dos prefijos en los verbos excardar y escavar, poniendo es al privativo EXCARDAR, que es quitar cardos, y ex a ESCAVAR, que es intensivo de cavar, cavar mejor, cavar menudo"; "otro error es conceder a las palabras que llama de evolución popular igual derecho que a las otras que llama de importación erudita"; "otro error es el de sostener que EXCAPAR no viene de EX y CAPIO, coger, capturar, sino de ex y cappa, que significa salirse de la capa..."; "otro error, y será el último que señale, por no alargar demasiado el artículo, es la afirmación de que el des de desCARNAR es distinto del de DESagraviar. No, señor. Son idénticos. Descarnar es quitar carnes, y desagraviar es quitar agravios". Pero, hemos de resaltar, Valbuena no se ha metido, por una vez, ni con la persona ni con ningún otro aspecto del señor Alemany.

\section{Polémica $10^{\mathrm{a}}$ : con Julio Casares, 1918}

Julio Casares era mucho más joven que Valbuena. A la altura de 1918, si Valbuena tenía ya 74 años, Julio Casares, nacido en 1877 , solo tenía 41. Ingresa en la Real Academia Española al año siguiente de esta polémica, en 1919 y llegará a ser Secretario perpetuo de la RAE desde 1936 hasta su muerte en 1964. Julio Casares publicaba en la prensa, en ese segundo decenio del siglo XX, una serie de artículos bajo el epígrafe de "Crítica efímera", que vieron la luz en dos tomos en 1918 y 1919, con el título de Crítica efímera. Divertimientos filológicos. Y en ellos va analizando y comentando los más diversos aspectos de la actualidad cultural lingüística y literaria. Con el irónico título de "Un crítico filológico (Don Antonio de Valbuena)", escribe nueve artículos, todos ellos con motivos relacionados con la lengua, la etimología, la gramática, recogidos en el tomo I de la Crítica efímera, pp.183-249. 
Dedica Casares los cuatro primeros artículos a la palabra "cierne" y expresión "en cierne", de la que había hablado Valbuena en su $\mathrm{Fe}$ de erratas. Empieza Casares su artículo primero así:

El distinguido dómine D. Antonio de Valbuena, que, con un poco de latín, un mucho de acrimonia y algo de sal común, viene amargando la vida a varias generaciones de académicos, arremete ahora de soslayo, en El Imparcial, contra Un chico del Instituto ${ }^{33}$, porque éste ha defendido la frase en cierne, usada por un académico, y porque se ha apoyado para ello en el Diccionario oficial. ;Doble claudicación!

Ni yo soy cirineo de nadie ni me parece mal que, con la debida cortesía, se formulen observaciones y censuras encaminadas a mejorar el inventario de nuestra lengua. No hace mucho tuve ocasión de rectificar un artículo del Diccionario, y hallé hospitalidad para hacerlo en el propio Boletín de la Academia. Pero de esto a tomar a chacota las definiciones del léxico oficial, ya sea por desconocimiento de la lengua clásica o porque, en clase de autoridades, la abuela del censor o el sacristán de su pueblo usaban o no tal o cual acepción, hay una respetable distancia.

Pasa luego a defender la expresión "en cierne", de la que Valbuena dice que se pronuncia "en cierna", y le da multitud de textos que sirven de autoridad. En los otros tres artículos dedicados a esta palabra y expresión se dedica Casares a justificar la voz "cierne" y expresión "en ciernes", su significado, su etimología. En el artículo dedicado a la etimología de "cierne" leemos:

Hasta que, ya en el siglo XIX, Bopp, Grimm y otros autores asentaron sobre bases científicas el estudio de la filología comparada, las etimologías solían fundarse en coincidencias, fortuitas o hábilmente amañadas, de forma o de significado [...]. Claro es que de semejante criterio etimológico no quedan ya vestigios en ninguna parte; solo en España podemos exhibir, en pleno siglo XX, al terrible Valbuena (D. Antonio de), sosteniendo en El Imparcial que "yesca" procede de "hayezca", por ser una "excrecencia del haya" (pp.203-204).

Los artículos $5^{\circ}$ y $6^{\circ}$ de esta serie, los titula Julio Casares "Huésped" y "Huéspeda". En el primero de esos artículos leemos:

Confieso que me causa tristeza contender con el tan celebrado autor de los Ripios, que vuelve ahora al palenque sin el ingenio y ga-

${ }^{33}$ Era el seudónimo con que firmaba sus artículos sobre asuntos de lengua Mariano de Cavia, mientras que usaba el seudónimo de Sobaquillo en sus crónicas taurinas. 
llardía de la juventud y con los mismos arreos, rudimentarios y maltrechos, que lució hace veinte o treinta años. Pero, como no es solo El Liberal quien tiene al Sr. Valbuena por "el más docto de nuestro críticos filológicos", no es lícito dejar que corran sin reparo sus dictámenes, so pena de convertirse, por mal entendido respeto, en encubridor de delitos contra el lenguaje y contra la verdadera doctrina filológica.

Ensalada de huéspedes titula su primer artículo el Sr. Valbuena, y en él saca a la pública vergüenza una larga serie de diccionarios, incluyendo, naturalmente, el de la Academia, para repartir sendos palmetazos a los "majaderos" autores, por el hecho de haber dado cabida a cierta acepción de huésped, que el Sr. Valbuena considera "irracional".

Julio Casares muestra con múltiples ejemplos que el término "huésped" ha significado a través de la historia lo mismo al que hospeda que al hospedado, contra la opìnión de Valbuena. En el segundo de esos dos artículos sigue Casares mostrando a Valbuena ejemplos de autores clásicos que avalan los dos significados de "huésped". Y termina el artículo: "Y aquí nos despediríamos por ahora del señor Valbuena si en su Ensalada de huéspedes no hubiese involucrado al humilde utensilio de cocina que veníamos llamando equivocadamente estropajo, cuando su verdadero nombre, según nuestro nunca bastante admirado crítico, es ESTRAPAJO. Pero este 'fregado' lo dejaremos para otra ocasión".

Y así es. El $7^{\circ}$ de los artículos de Casares titula "Estropajo". Ya en el párrafo tercero leemos: "Realmente, la ocurrencia del Sr. Valbuena no puede ser más peregrina. Asegura, y no seré yo quien lo niegue, que en la "tierra clásica del bien hablar" (Léase Pedrosa del Rey, pueblo de la provincia de León, cuna del "más docto crítico filológico" del siglo XX), se dice estrapajo y no estropajo". Habla a continuación Casares de la etimología popular, citando varios ejemplos, y continúa: "Idéntico proceso mental deben de haber seguido los familiares y convecinos del Sr. Valbuena, para trocar en estrapajo el estropajo común en toda España. [...] ¿Supone el Sr. Valbuena que de su estrapajo, meramente local, del cual no hay el menor vestigio en la lengua antigua, han salido los vocablos castellanos estropajo, estropajoso, estropajosamente, estropajeo y estropajear, amén del portugués estropalho, y del italiano stroppaglio? No; el Sr. Valbuena no supone eso... ni lo contrario, sencillamente porque desconoce los datos del problema que ha planteado sin saberlo". 
El artículo $8^{\circ}$ de Julio Casares se titula "Yesca" y empieza burlándose de Valbuena. Dice después que la sección de Valbuena "Ni limpia ni fija", "fracasada en El Liberal", ha pasado a El Imparcial, donde "nuestro avinagrado preceptor se ha encaramado [...] y ya le tenemos otra vez a sus anchas, desbarrando doctoralmente". Pasa Casares a mostrar que 'yesca' es palabra que proviene del latín esca, comida, alimento, y no de 'hayezca', como dice Valbuena: "Confieso -dice Casares- que me da vergüenza enseñar a estas alturas cosas tan elementales a todo un señor "crítico filológico", que lleva casi medio siglo repartiendo palmetazos; pero, ¿es posible, es decoroso siquiera hablar de "las leyes de transformación de las palabras", ignorando hasta el abecé de la lingüística? Y acaba este artículo $8^{\circ}$ de Casares:

Como se ve, todo el artículo es una verdadera fantasía "valbuenezca".

¿Quiere usted, Sr. Valbuena, escuchar un consejo leal? Jubíle$\mathrm{se}^{34}$. Aún perdura el recuerdo de los primeros Ripios y de las carcajadas con que fueron acogidas las agudezas de la $\mathrm{Fe}$ de erratas. Conténtese con ese recuerdo; piense que los tiempos han cambiado y medite la triste diferencia que hay entre hacer reír a costa ajena y servir de irrisión por cuenta propia. (Crítica efímera, I, p.242).

Por fin, Casares dedica un último artículo a Valbuena titulado ¿'Aja' o ‘Ajajá!'?, en el que, básicamente, le afea que no haya entendido el nombre propio 'Aja', escrito también como Haja, Haxa, Axa y Aixa, como un nombre de mujer muy frecuente en el mundo musulmán, y lo haya interpretado como una interjección, equivalente a 'Ajajá'. Y aprovecha el escrito Casares para burlarse de Valbuena llamándole (p.243) "el Cicerón de Pedrosa del Rey", "el paladín del ESTRAPAJO", "el Emperador del habla castellana", "El Cicerón leonés".

¿Y qué dijo Valbuena ante esta insistencia, interés e ironía de Julio Casares? Valbuena, a sus 74 años, se niega a enmudecer. Publica aún en El diario de la Marina ${ }^{35}$, publica en El Liberal y en El Imparcial, como acabamos de ver. A varios de esos artículos en El Liberal y en El Imparcial ya ha aludido Casares. Recogemos ahora, dentro de esta polémica, algunas afirmaciones publicadas el 28 de agosto de

${ }^{34}$ Ya dijimos al iniciar esta polémica que a la altura de 1918 Valbuena tenía 74 años y Casares 41.

${ }^{35}$ Del 6 de junio de 1915 tenemos un artículo en El Diario de la Marina, de La Habana, en la sección "La que limpia, fija y da esplendor", en el que habla de los 'errores' en que incurre el Diccionario de la RAE en la palabra 'juicio'. 
1918, en la sección "A la que salta", bajo el título de "Nuevas casarerías": Los improperios y los insultos de Casares no necesito rechazarlos, no me hieren, rebotan en la coraza de mi hombría de bien y de mi formalidad de toda la vida y se vuelven contra el que los ha disparado. [...] No es nuevo en Casares el procedimiento de desfigurar la verdad o sustituirla con la mentira, para defender sus disparates y aun los ajenos.

Pasa después a hablar de la expresión "en cierne" por la que tanto han debatido, dice en un momento "Las mentiras casariegas de ahora...", y poco después:

Luego, tras un largo párrafo lleno de insolencias, y otro más corto en que todavía protesta carnerilmente contra el ESTRAPAJO, voz etimológica y legítima, sustituida por el palurdismo estropajo en el Diccionario académico, vuelve a mentir Casares [...]

Solo a Casares, esencialmente soso, podrá ocurrírsele esa broma en estos tiempos".

\section{Polémica 11ª : con Julio Cejador, 1918}

Julio Cejador (Zaragoza 1864-Madrid 1927) era veinte años más joven que Valbuena. Había sido jesuita y dejó la Compañía en 1899. Fue catedrático de Latín en la Universidad Central de Madrid. Publicó numerosos artículos y libros sobre el lenguaje y sobre literatura, e incluso tiene obra narrativa.

En el Diccionario Espasa, al llegar a la voz 'Valbuena', se le dedica un amplio espacio y recoge la opinión de Julio Cejador sobre Antonio de Valbuena: "Fue luego -dice Cejador- sacando ripios y faltas de lenguaje a poetas españoles y americanos, con sátira mordaz y atrevida, pasando de lo literario a lo político y aun a lo personal. El genio agrio, intransigente y duro como de acero, del escritor, se ensaña en cuanto a tuerto o a derecho pueda servir de burla y hacer soltar la carcajada al lector. Su vis cómica es mucha, aunque poco fina y menos ática. Son sales gordas, que despiertan el apetito de comerse vivas las carnes de escritores y personas de cuenta. El público lanzose con voracidad nunca saciada; engullía, devoraba aquellos librajos, donde en tono magistral, y no sin conocimientos idiomáticos, despedazaba frases, afeaba voces, abatía nombres encumbrados, hacía befa hasta del vestir, del porte y maneras de afamados escritores, con frase castiza, donairoso decir, desplantes inauditos..."

Valbuena publica en ¿El Imparcial? un artículo el 25 de julio de 1918, en la sección "A la que salta”, bajo el título “¿Otro Casares?”. 
La polémica en este caso se centra en la distinta interpretación que de los prefijos ex- y es- hacen Cejador y Valbuena, como ya antes habíamos visto con Valbuena y Alemany. Pero, al lado de los aspectos lingüísticos, Valbuena, como tantas veces, saca a relucir otros temas.

También se llama Julio -empieza diciendo Valbuena-, pero no se apellida Casares, sino Cejador, apellido que parece que obliga. Sabido es que cejar es andar para atrás.

Este Cejador es literariamente un pobre diablo, que dicen que de joven ingresó en la Compañía de Jesús, pero la dejó pronto; de suerte que no es jesuita, sino ex jesuita, lo cual no es lo mismo, sino lo contrario, aun cuando él, por andar al revés, dice que es idéntico.

Se parece a Casares ${ }^{36}$, no solamente en llamarse Julio, sino además en saber poco, y además en querer aparentar que sabe muchísimo. Pero le aventaja evidentemente en una cualidad: en la falta de sentido común [...]; pero en Cejador esa misma falta es radical, absoluta, completa.

Después de esta presentación, pasa Valbuena a recordarle unas afirmaciones de hacía quince años:

"Quince años va a hacer en noviembre que este Cejador publicó unos artículos titulados "Idolillos de gramáticos", echándoselas de gran filólogo y demostrando en ellos grandísima ignorancia filológica y carencia total del sentido indicado [...] guiente:

Después de esta muestra de mal gusto, llegaba a decir lo si-

"El labriego de tierra de Campos no se ha metido a distinguir una letra de otra en su habla, no sabe si pronuncia $\mathrm{m}$ o $\mathrm{n}$ al decir a su mujer que se va al campo. Pero el que tenga buen oído notará que ese labriego no dice CAMPO, sino canpo".

¿Qué barbaridad!, me figuro que dice todo lector, porque esa misma exclamación hice yo la primera vez que lo leí.

Este insensato no se ha enterado todavía de que es imposible pronunciar la palabra canpo con ene, porque preparados los labios para pronunciar la pe inmediata, pronuncian necesariamente la eme. $Y$ también es imposible enunciar y sostener mayor majadería ni mayor disparate. [...]

$Y$ ciertamente que ningún labriego de tierra de Campos ni de ninguna tierra se habrá entretenido en pronunciar así para que lo

${ }^{36}$ Valbuena alude aquí a Casares porque llevaba en paralelo, por los mismos meses, la doble polémica, con Casares y con Cejador. 
oyera Cejador, con tan buen oído como mal entendimiento. Tan malo, que le hace continuar cejando bárbaramente de esta forma...”.

Una vez que le recuerda ese 'pecado' de hace "quince años", pasa Valbuena a la actualidad:

Bueno; pues ahora este ignorador de la fonética y de la sintaxis [...] sale en La Tribuna dándose tono, diciéndose mi discípulo y anunciando que va dar al maestro cuchillada.

Puesto a ello, empieza llamando palos de ciego a los palos que con buena vista, gracias a Dios, y bien dirigidos y bien sentados, he dado recientemente a la Academia por la caprichosa e irracional ortografía que usa en su Diccionario [...]

$Y$, últimamente, ¿qué autoridad puede tener en materia de sonidos y de pronunciaciones el autor de la estrafalaria y absurda afirmación de que se puede y se debe pronunciar y el labriego pronuncia canpo con ene?

Absolutamente ninguna.

Por eso no resulta lo de la cuchillada al maestro.

No hay tal cuchillada.

Eso no es más que una botaratada.

\section{Conclusión}

Valbuena -acabamos de ver- fue un gran polemista. Vivía de la polémica, revivía con la polémica, buscaba y alimentaba la polémica. En realidad, Valbuena fue un gran periodista. Vivió de su pluma, del sudor diario del artículo para el periódico, del esfuerzo de conquistar al público. Vencido en la guerra (en la $3^{\mathrm{a}}$ carlista), vencido en la vida política (no salió elegido diputado cuando se presentó en dos ocasiones ${ }^{37}$ ), fue un gran vencedor durante varios años en el mundillo cultural del periodismo. Y para sus victorias usó sus armas: la polémica, el ataque a personajes de todo tipo, una ideología ultraconservadora, una ortodoxia religiosa, católica sin fisuras, y, sobre todo, el estilo ágil, el tono entre festivo, burlón y satírico, la cercanía y complicidad con el lector, un ingenio agudo y rápido, capaz de sacar chispa y chiste de cualquier cosa. Y mucho esfuerzo, mucho trabajo: alrededor de treinta libros, la mayoría de crítica, con las lecturas y consultas que ello exige, algunos narrativos (narrativa larga o novela, narrativa corta o cuentos), dos libros de poesía, uno de caza, alguna traducción.

Incansable buscador del defecto ajeno, sobre todo del defecto lingüístico, del error gramatical, de la deficiencia en la definición lexi-

\footnotetext{
${ }^{37}$ Ver F. de la Cuesta, ob. cit. p.18.
} 
cográfica, de la errónea etimología, de la inadmisible grafía, de la abundante incoherencia, de la cacofonía, de la falta de lógica, del multipresente ripio, de la continua vulgaridad, de los violentos hipérbatos, de la rima forzada, de la permanente cursilería, del engolamiento y lenguaje rimbombante, de... ¡Cuántas cosas echa en cara Valbuena a los escritos de sus contemporáneos! Pero "son numerosos los casos en que Valbuena lleva razón [...] El aviso del crítico era, pues, muy útil" (Zamora Vicente, 1999, 518).

$\mathrm{Si}$ a esto añadimos su "popularidad estrepitosa" (Azorín); si recordamos que "es favorito de la juventud (los muchachos entre quince y veinte se lo saben de memoria)" (Pardo Bazán); si admitimos que "es un escritor satírico tal como le piden nuestra lengua y nuestra raza" (Clarín); si creemos a sus 'enemigos' que reconocen, treinta años después, que "aun perdura el recuerdo de los primeros Ripios y de las carcajadas con que fueron acogidas las agudezas de su Fe de erratas" (Julio Casares); si Menéndez Pelayo no escribirá la historia de la sátira en España "por no nombrarle"; si "no resulta equivocado afirmar que el Clarín de los paliques y el Valbuena de los Ripios fueron en su día los críticos literarios más populares" (Martínez Cachero, ob. cit. p.3334); si sus "artículos se pagan a precio de oro" (Soiza Reilly); si todo esto es así, estamos ante un escritor grande: grande por su fama, grande por la cantidad de obra publicada, grande por la calidad de su estilo, grande por el fuego que atizó, grande por la influencia que logró, grande incluso por los 'adversarios ' con los que polemizó. Polémicas, principalmente sobre corrección gramatical y 'defectos' del Diccionario de la Academia, de las que aquí hemos dado cuenta.

\section{Referencias bibliográficas}

ALAS “Clarín”, L. (1973) Palique, ed. de J.M Martínez Cachero, Barcelona (Lábor).

ALGABA PACIOS, Nieves (1999) "La singularidad del leonés Antonio de Valbuena en la cronología noventayochista", en Actas del Congreso de Castilla y León ante el 98 (Junta de Castilla y León, Consejería de Educación y Cultura) 1999.

ALGABA PACIOS, Nieves (2001) Antonio de Valbuena. Prosa críti$c a$, León (Breviarios de la calle del Pez) pp.309-326.

BARREIRO, Javier (1999) "Antonio de Valbuena, azote de poetas ripiosos", en AAVV, Oscura turba de los más raros escritores españoles. Zaragoza (Xordica).

BLANCO GARCÍA, Francisco (1903) La literatura española en el siglo XIX, parte II, , $2^{\mathrm{a}}$ ed., Madrid. 
BOTREL, Jean-François (1971) "Cartas a Antonio de Valbuena "Miguel de Escalada" (Copia y notas de J.F.Botrel), en Tierras de León $\mathrm{n}^{\mathrm{o}}$ 14, pp.13-35, León.

BOTREL, Jean-François (1984) "Antonio de Valbuena y la novela de edificación (1879-1903)", Tierras de León, $\mathrm{n}^{\circ}$ 55, pp.131-144, León.

CASARES, Julio (1918) Crítica efímera, 2 vol. Madrid (edit. Saturnino Calleja).

CUESTA, Filemón de la (1944) Valbuena y sus poesía, "Diario de León", León.

DÍAZ-PLAJA, Guillermo (1979) Modernismo frente a Noventa y Ocho. Madrid (Espasa Calpe).

FERNÁNDEZ FERNÁNDEZ, Simona (1975) Biografía y crítica literaria de Antonio de Valbuena (1844-1929). Tesis de licenciatura presentada en la Universidad de Oviedo el 5 de julio de 1975. Inédita.

FERNÁNDEZ SHAW, Guillermo (1969) Un poeta de transición. Vida y obra de Carlos Fernández-Shaw (1865-1911), Madrid (Gredos).

FRAY MORTERO (Fray Juan de Miguel) (1892) Cascotes y machaqueos. Pulverizaciones a Valbuena y Clarín, Madrid (Libr. de la Viuda de Hernando y Cía).

MARTINEZ CACHERO, José (1998) Diccionario de grandes figuras literarias, Madrid (Espasa).

MARTÍNEZ GARCÍA, Francisco (1982) Historia de la Literatura Leonesa, León (Everest).

PARDO BAZÁN, Emilia (1891) Nuevo teatro crítico, $\mathrm{n}^{\circ}$ 9. Madrid.

SERRANO SERRANO, Joaquín y Fernández Fernández, Simona (1981) "Antonio de Valbuena, ilustre escritor leonés del siglo XIX”, Tierras de León n $\mathrm{n}^{\circ}$ 42, pp.99-110, León.

SERRANO SERRANO, Joaquín y Fernández Fernández, Simona (1991) "Antonio de Valbuena. Luces y sombras en sus críticas", en Tierras de León, $\mathrm{n}^{\circ} 81$ y 82, León.

SOIZA REILLY, Juan José (1909) "Antonio de Valbuena, un crítico terrible", en Cien hombres célebres. Confesiones literarias, Barcelona (Maucci) pp.285-288.

ZAMORA VICENTE, Alonso (1999) La Real Academia española. Madrid (Espasa). 